Terbit online pada laman web jurnal: http://jurnal.iaii.or.id

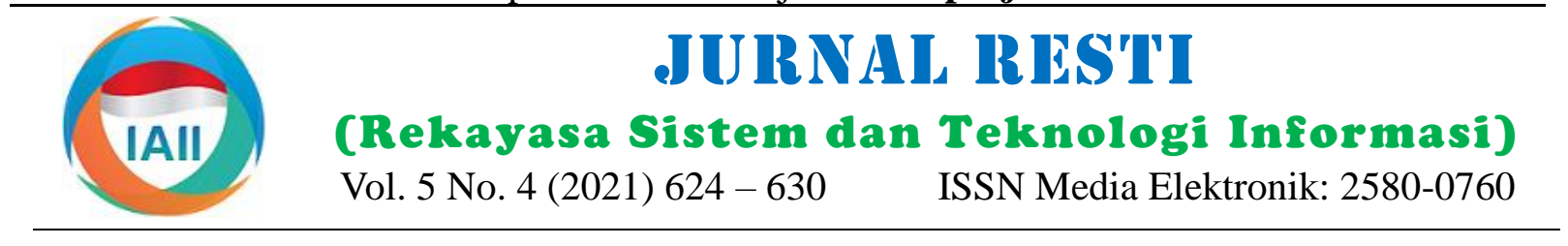

\title{
Implementasi Convolutional Neural Network Untuk Deteksi Nyeri Bayi Melalui Citra Wajah Dengan YOLO
}

\author{
Tomy Abuzairi ${ }^{1}$, Nurdina Widanti ${ }^{2}$, Arie Kusumaningrum ${ }^{3}$, Yeni Rustina ${ }^{4}$ \\ ${ }^{1}$ Teknik Elektro, Departemen Teknik Elektro, Fakultas Teknik, Universitas Indonesia \\ ${ }^{2}$ Teknik Biomedis, Departemen Teknik Elektro, Fakultas Teknik, Universitas Indonesia \\ ${ }^{3,4}$ Fakultas Ilmu Keperawatan, Universitas Indonesia \\ tomy.abuzairi@ui.ac.id
}

\begin{abstract}
Pain in a baby is difficult to detect is because the method for detecting pain is self-reporting even though babies themselves still cannot describe the pain verbally, then by observing changes in behavior in the form of facial expressions. Statistically, it is also recorded that about $80 \%$ of the world's population pays less attention to pain assessment, especially for children, even though this pain gives children a bad experience so that it can interfere with pain responses in the future or psychological trauma. Based on these problems, a prototype system was made using the NVIDIA Jetson Nano Developer kit to help detect pain, especially in infants 0-12 months by using the Convolutional Neural Network (CNN) model with the PyTorch framework and the You Only Look Once (YOLO) algorithm with three detection classification is sad, neutral and sick. From the results of the study, it was found that the YOLO algorithm was able to detect the three classifications with mAP@0.5 value of sad 97,9\%, neutral 99,2\%, pain 96,9\%, model accuracy 70\%. The result of random check and the data from Puskesam Imogiri 1 have accuracy value $90 \%$.
\end{abstract}

Keywords: NVDIA Jetson Nano Developer Kit, Pain, Baby, YOLO, PyTorch, CNN, Facial Expresion.

\begin{abstract}
Abstrak
Rasa nyeri yang kerap kali dirasakan oleh bayi dan sulit dideteksi hal ini dikarenakan metode untuk mendeteksi rasa nyeri bersifat self-reporting padahal untuk bayi sendiri masih belum dapat menjabarkan rasa nyeri tersebut dengan verbal, maka dengan mengamati perubahan perilaku berupa ekpresi wajah. Secara statistic juga tercatat sekitar $80 \%$ dari populasi dunia kurang memperhatikan penilaian rasa nyeri terutama terhadap anak-anak padahal rasa nyeri ini memberi pengalaman yang buruk pada anak, sehingga dapat mengganggu respon nyeri di kemudian hari atau trauma psikis. Berdasarkan permasalahan tersebut maka dibuatlah sebuah sistem prototipe dengan menggunakan NVIDIA Jetson Nano Developer kit untuk membantu mendeteksi rasa nyeri terutama pada bayi 0-12 bulan dengan menggunakan model Convolutional Neural Network (CNN) dengan framework pytorch dan algoritma You Only Look Once (YOLO) dengan tiga klasifikasi pedeteksi yaitu sedih, netral dan nyeri. Dari hasil penelitian diperoleh hasil bahwa algoritma YOLO sudah dapat mendeteksi ke tiga klasifikasi tersebut dengan nilai mAP@0.5 sedih 97,9\%, netral 99,2\%, pada nyeri 96,9\% dan akurasi model 70\%. Hasil dari uji data acak dan data dari Puskesmas Imogiri 1 diperoleh nilai akurasi sebesar $90 \%$.
\end{abstract}

Kata kunci: NVDIA Jetson Nano Developer Kit, Nyeri, bayi, YOLO, Pytorch, CNN, Ekspresi Wajah.

\section{Pendahuluan}

Dengan semakin pesatnya kemajuan teknologi computer vision, salah satunya dengan memanfaatkan data citra wajah. Pengenalan citra wajah banyak digunakan untuk aplikasi presensi kelas dengan senyum [1], pengenalan wajah perokok [2], intensitas emosi [3], klasifikasi kelompok usia [4], dan untuk mendeteksi rasa nyeri[5].

Rasa nyeri adalah salah satu cara tubuh untuk seperti imunisasi, perawatan gigi, pungsi vena, maupun mengatakan bahwa ada sesuatu yang salah pada tubuh. pemasangan infus.
Menurut International Association for the Study of Pain (IASP) rasa nyeri adalah pengalaman perasaan emosional yang tidak menyenangkan akibat terjadinya kerusakan aktual maupun potensial [6]. Nyeri yang dirasakan bayi merupakan dampak dari penyakit yang dialami dan dampak dari tindakan klinik. Tindakan klinik ini dapat dikatagorikan sebagai nyeri prosedural yaitu nyeri yang diakibatkan adanya prosedur medis 
Maka dari itu penanganan dan juga penilaian terhadap Beberapa penelitian sebelumnya terkait memberikan rasa nyeri ini perlu diperhatikan. Penilaian rasa nyeri solusi dengan menggunakan data rekaman video lalu terhadap anak-anak sulit sekali dilakukan karena metode dianalisa dengan penilaian menggunakan metode Non yang sering dilakukan adalah self-reprorting [7]. Untuk verbal pain scale revised (NVPSR) yang memiliki menunjang penilaian tersebut terdapat beberapa cara korelasi yang kuat dengan WBPS dalam menilai nyeri salah satunya yaitu melihat perubahan perilaku yang pada anak. Sensitifitas yang cukup tinggi sebagai alat berkaitan dengan nyeri dapat dilihat dari ekspresi wajah skrening nyeri namun memiliki spesifitas yang sedang serta respon verbal dari seseorang yang mengalami sebagai alat diagnostik nyeri pada anak [14], lalu nyeri. Tidak seperti orang dewasa, bayi tidak bisa terdapat juga pengembangan dengan menggunakan mengungkapkan rasa nyeri secara verbal. Namun wajah bayi, suara. Di mana pergerakan diambil dengan demikian rasa nyeri dapat diprediksi dengan mengenali menggunakan kamera go-pro lalu dengan menggunakan reaksi bayi.[8], [9], atau dapat juga menangkap aktivitas metode machine learning, svm classifier, dengan output kelenjar keringat [10][11].

Beberapa metode yang sering digunakan untuk mengukur tingkat rasa nyeri pada anak adalah metode Visual Analog Scale (VAS), Verbal Rating Scale (VRS), Numeric Rating Scale (NRS), Wong Baker Pain Rating Oleh karena itu, pada penelitian ini, kami Scale [12], Neonatal/Infant Pain Scale (NIPS), Faces mengembangkan sebuah monitoring rasa nyeri terhadap Legs Activity Cry Consolability Revised Scale (FLACC- bayi dimana penanganan awal berupa monitoring R)[13]. Skala nyeri seperti Wong Baker pain scale, terhadap rasa nyeri dapat digunakan pada unit comfort scales, dan sebagainya umumnya tidak bisa perawatan. Hasil monitoring tersebut digunakan untuk menginterpretasikan nyeri secara keseluruhan, melakukan jenis tindakan pemulihan nyeri dan sedangkan nonverbal pain scale (NVPS) memiliki ketidaknyamanan lebih awal agar tidak menciptakan korelasi yang lebih kuat dalam mendeteksi rasa nyeri rasa trauma berkepanjangan terhadap bayi. Penelitian ini [14].

Perubahan ekspresi wajah pada bayi apakah merasa nyeri atau merasakan hal lain bisa dilihat dari perubahan pada alis, mata, mulut dan hidung. Jika bayi merasakan nyeri maka alis agak menurun, mulut terbuka condong membentuk persegi, mata tertutup rapat [5], [8], [9], [15][16]. Data perubahan wajah tersebut yang nantinya akan dilatih dengan memanfaatkan algoritma deep learning yaitu algoritma YOLO (You Only Look Once). Dengan tujuan mempermudah pendeteksian rasa nyeri pada bayi.

Deep learning yang digunakan untuk mendeteksi suatu objek membutuhkan komputasi power yang tinggi dan dibutuhkan framework yang dapat mengimplementasikan citra dengan optimal. PyTorch merupakan pengembangan dari Torch Framework yang awalnya berbahasa pemrograman Lua. Dibanding dengan framework lain, PyTorch memiliki sintaks yang lebih rapi dan sederhana. PyTorch memudahkan pengguna untuk menjalankan proses perhitungan pada GPU menggunakan CUDA framework[17].

You Only Look Once (YOLO) merupakan sebuah metode yang dihasilkan oleh Joseph Redmon untuk melakukan Object Detection[18][19] yang memanfaatkan jaringan syaraf konvolusional (CNN) dalam mendeteksi objek. Di mana citra akan dibagi ke dalam grid berukuran $s \quad x \quad s$ dari setia grid akan memprediksi bounding box serta peta kelas masingmasing grid. Apabila pada satu grid terprediksi objek, maka pada grid tersebut akan diprediksi bounding box yang mengelilingi objek tersebut. dibangun dengan menggunakan parameter perubahan emosi wajah bayi yang dikatagorikan menjadi 3, yaitu netral, sedih dan nyeri, dengan user interface berupa web monitoring system yang dapat diakses oleh siapapun tanpa harus melakukan install program.

\section{Metode Penelitian}

Untuk meneliti rasa nyeri pada bayi dengan rentang umur 0-12 bulan yang melakukan prosedur medis berupa suntik imunisasi IPV dan juga Pentabio paada kaki bayi. Penelitian ini dilakuakn di beberapa puskesmas di Yogyakarta, salah satunya adalah Puskemas 1 Imogiri. Dimana untuk blok diagram sistem ditunjukan pada Gambar 1.

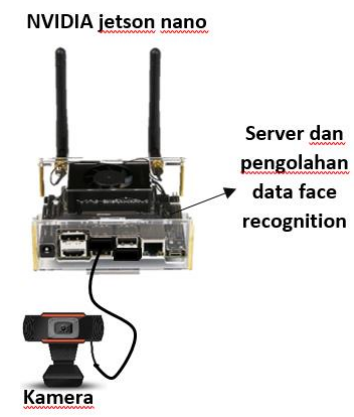

Gambar 1. Blok Diagram Sistem

Untuk membangun sistem pendeteksi rasa nyeri ini dimulai dengan membuat dataset, training dan testing citra tersebut dan membuat user interface. Untuk sumber dataset akan dibuat sendiri dikarenakan objek yang diteliti memiliki rentang umur yang cukup kecil yaitu 0-

DOI: https://doi.org/10.29207/resti.v5i4.3184

Creative Commons Attribution 4.0 International License (CC BY 4.0) 
12 bulan, pada the child affective facial expression set (CAFÉ)[22] juga menyediakan dataset utuk anak-anak tetapi rentang umur yang tersedia mulai dari 2 tahun sampai 8 tahun.

\subsection{Pembuatan Dataset}

Pembuatan dataset dimulai dengan menentukan klasifikasi emosi yang akan dideteksi yaitu nyeri, netral dan sedih. Setelah menentukan klasifikasi dan juga rentang umur maka selanjutnya mengumpulkan data gambar, sebanyak 600 data gambar di kumpulkan dengan berbagai posisi bayi, seperti yang ditunjukan pada Gambar 2.

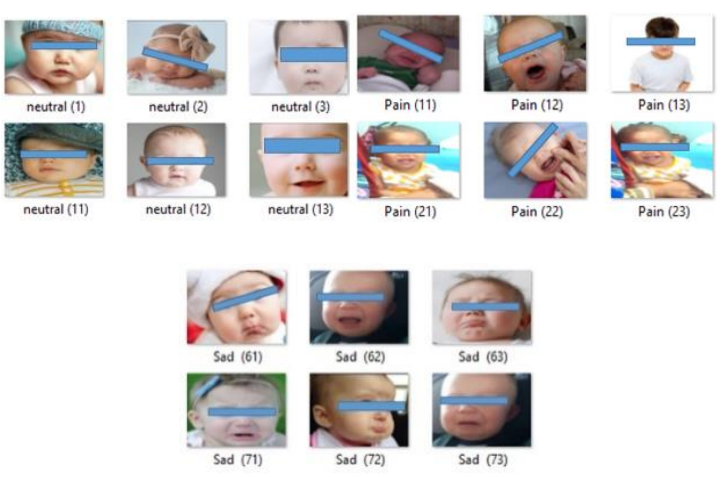

Gambar 2. Data Gambar Untuk Training

Data ekspresi yang disiapkan mengacu pada literatur yang ada [5], [8], [9],[15],[16]. Proses selanjutnya adalah labeling dengan menggunakan tools labelme. Proses labeling ini dimulai dengan membuat bounding box beserta nama kelas pada setiap objek di mana data citra yang berformat .jpeg akan diubah menjadi .json. pada file .json ini akan berisi informasi yang nantinya akan digunakan untuk membuat algoritma YOLO. Pada Gambar 3 menunjukan proses labeling data.

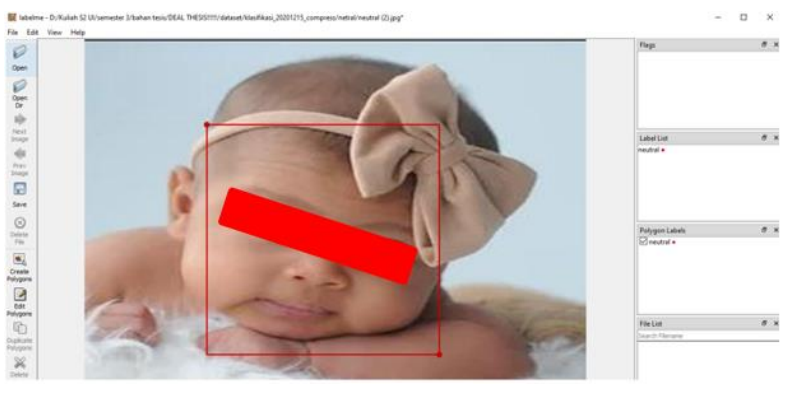

Gambar 3. Proses Labeling Dengan Labelme

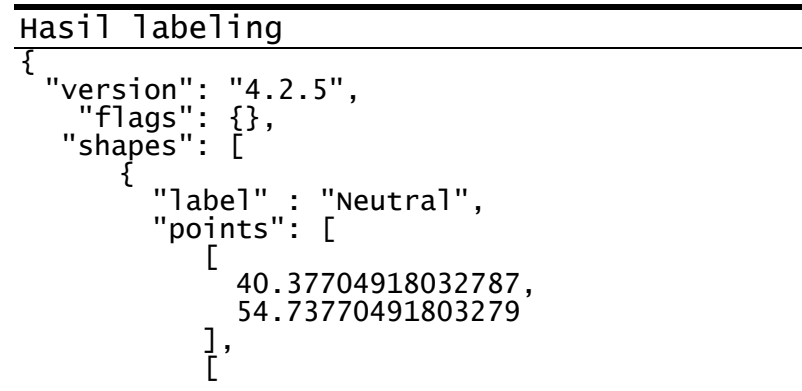

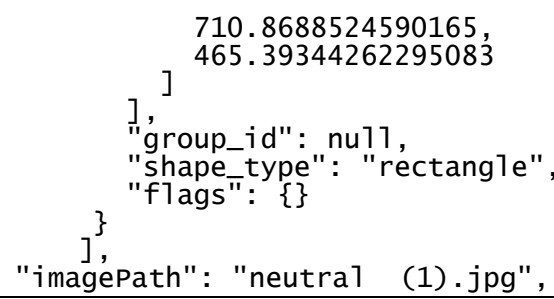

\subsection{Konversi Data Citra ke YOLO}

Data yang diperoleh dari hasil labelme ini harus di konversi dengan menggunakan preprocessing tool menggunakan phyton 3.7. proses ini bertujuan untuk untuk membuat data dari.json menjadi data yang berkualitas dan siap digunakan pada algoritma YOLO.

Langkah dalam melakukan preprocessing data. Data cleaning mengisi missing value, mengidentifikasi outlier, menangani data noise, mengoreksi data yang tidak konsisten, dan menyelesaikan masalah redudansi data akibat integrasi data. Mengintegrasikan skema, mengidentifikasi masalah entitas, dan mendeteksi sekaligus menyelesaikan konflik pada nilai data. Melakukan cek data, apakah bboxnya sudah sesuai dengan waktu awal tagging di labelme. Meng-agregasi data, generalisasi data, normalisasi data, dan pembentukan atribut/fitur.

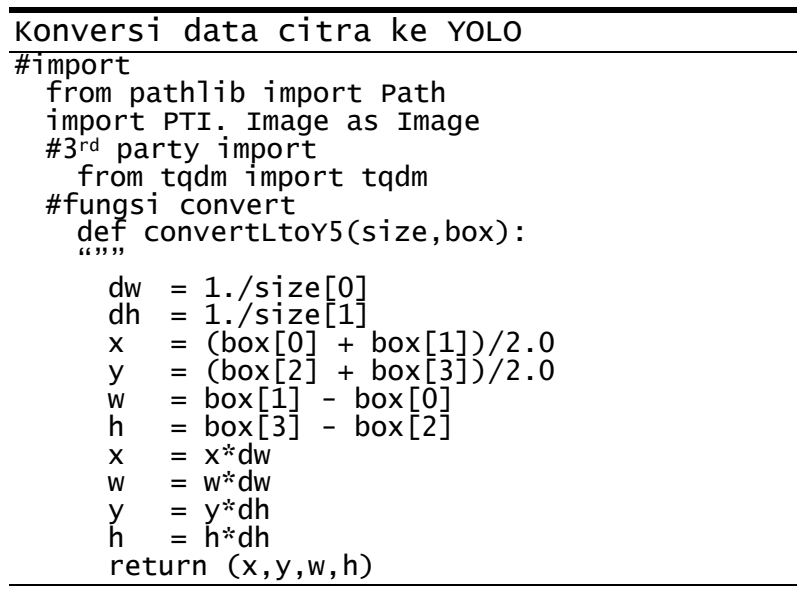

\subsection{Training, Validasi, dan Testing}

Data training ini dilakukan setelah didapatkan anotasi dari kelas-kelas objek yang dideteksi, parameter yang digunakan untuk melakukan training yang pertama adalah epoch banyaknya iterasi pelatihan data, lalu batch banyaknya data yang dipelajari tiap iterasi, ini biasanya disesuaikan dengan total data yang kita miliki dan kemampuan mesin kita mengolahnya, selanjutnya tradeoff jika datanya $<10 \mathrm{~K}$ data maka batch tidak bisa besar meski VGA mumpuni, misal VRAMnya 12 GB, lalu ukuran gambar 240 px konsep pembacaan datanya seperti skimming. Model (FLOPS) menentukan VRAM yang dipakai di VGA, jenis FLOPS menentukan akurasi (IoU) maksimum dan menentukan FPS (frame per second).

DOI: https://doi.org/10.29207/resti.v5i4.3184

Creative Commons Attribution 4.0 International License (CC BY 4.0) 
Setelah dilakukan training dengan baik maka 2.4. Metode Evaluasi.

dilanjutkan untuk menvalidasi data tersebut, proses ini bertujuan untuk melihat bagaimana kinerja hasil training yang diperoleh. Cara untuk melakukan validasi yaitu ambil $20 \%$ sampai $25 \%$ data train, ubah menjadi data

Terdapat beberapa metode untuk mengevaluasi kinerja sistem, yaitu recall, presisi, F1 score, Intersection over Union, mean Average Precision, dan Akurasi.

val, pindahkan data val $20 \%$ tersebut ke dalam folder val Recall didefnisikan sebagai rasio dari jumlah total jangan tertukar label dengan image, buat setting yaml di contoh positif yang diklasifikasikan dengan benar dibagi YOLO, dan terakhir buat shell script untuk train dan dengan jumlah total contoh positif. Recall yang tinggi inference. Hasil nilai evaluasi ini akan terlihat pada nilai menunjukkan bahwa kelas dikenali dengan benar (FN mAP yang akan tertera di akhir setelah sistem sedikit), seperti terlihat pada persamaan 1. melakukan proses sesuai script dibawah ini.

Script train dan inference

python train.py --img 320 --batch 2 --epochs 50 --data dina.yam1 --weights yolov3.pt

python detect.py --source test-data/ --weights runs/train/exp3/weights/best.pt --conf 0.25

format data yang diperoleh setelah melakukan training dan validasi akan muncul

\begin{tabular}{l} 
Format Data \\
\hline Train: \\
/run/media/dina/Binary/WorkCode/projects/Ronti \\
a/rontia-ashengine/images/train \\
Va1: \\
/run/media/dina/Binary/WorkCode/projects/Ronti \\
a/rontia-ashengine/images/val nc: 3 \\
names: \\
['Neutral', 'Pain', 'Sad']
\end{tabular}

Untuk proses data testing ini akan dipersiapkan sejumlah gambar, di mana pada tahap ini akan disiapkan 75 gambar uji diluar data training. Setelah di testing maka akan dilakukan evalusi dengan beberapa metode evaluasi.

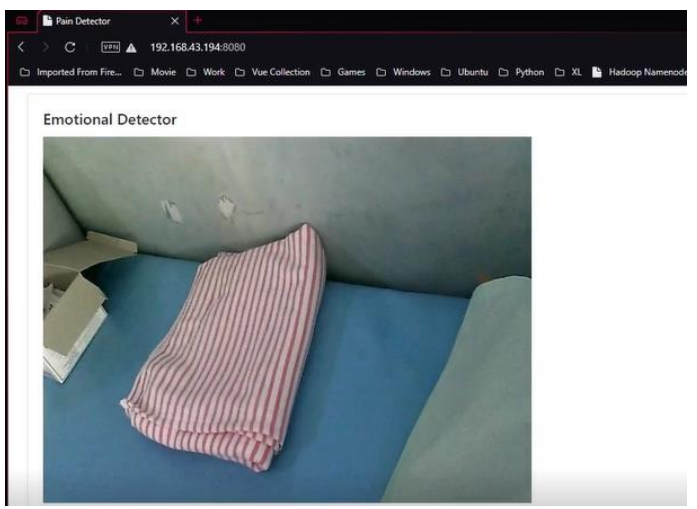

Gambar 4. Web Pain Monitoring System
Recall $=\frac{T P}{T P+F N}$

Nilai presisi didapatkan dengan cara membagi jumlah total contoh positif yang diklasifikasikan dengan benar dengan jumlah total contoh positif yang diprediksi, seperti terlihat pada persamaan 2 .

Presisi $=\frac{T P}{T P+F P}$

Dimana True Positive (TP) merupakan nilai aktual bernilai positif dan diprediksi positif juga, sedangkan True Negative (TN) merupakan nilai aktual bernilai negatif dan diprediksi negatif juga. False Positive (FP) merupkan nilai aktual bernilai negatif tetapi diprediksi positif, sedangkan False Negative (FN) merupakan nilai aktual bernilai positif tetapi diprediksi negatif.

Kondisi dimana Recall tinggi dan Presisi rendah artinya sebagian besar contoh positif dikenali dengan benar (FN rendah) tetapi ada banyak positif palsu (FP tinggi). Sedangkan kondisi Recall rendah dan Presisi tinggi artinya kehilangan banyak contoh positif (FN tinggi) dengan nilai positif palsu yang sedikit (FP rendah).

F1 Score merupakan perbandingan rata-rata presisi dan recall yang dibobotkan sesuai dengan persamaan 3 .

$F 1$ score $=2 \times \frac{\text { Recal } \times \text { precision }}{\text { Recal }+ \text { precision }}$

Intersection over Union (IoU) merupakan metrik evaluasi untuk mengukur keakuratan detektor objek pada dataset tertentu. IoU dapat digunakan dengan ketentuan memiliki ground-truth bounding box pada dataset objek dan juga prediksi bounding box pada dataset objek. IoU merupakan perbandingan antara ground-truth bounding box dengan predicted bounding box pada model.

mean Average Precision (mAP) merupakan nilai ratarata dari Average Precision (AP) yang membentuk metrik evaluasi untuk mengukur kinerja dari sebuah deteksi objek.

ada alat pain monitoring ini data akan ditampilkan Untuk mendeteksi atau melihat akurasi pada model yang langsung pada web yang mana web tersebut dapat telah dibuat akan di uji coba dengan 100 gambar acak diakses oleh banyak orang tanpa orang tersebut dan akan di analisa dengan menggunakan persamaan mendownload atau menginstall sesuatu. Gambar 4 dengan persamaan 4. menunjukan web pain monitoring system. 


$$
\text { Akurasi }=\frac{\text { Jumlah data yang benar }}{\text { jumlah data keseluruhan }} \times 100 \%
$$

(4)

\section{Hasil dan Pembahasan}

Pada pengujian face recognition ini dibagi menjadi 2 tahap. Tahap pertama yaitu evaluasi model. Tahap kedua yaitu tahap pengujian terhadap data acak yang diambil dari internet dan juga data bayi yang saat pengujian langsung di Puskesmas Imogiri 1. Pertama data akan di ambil oleh webcam yang diletakan di kasur pasien atau dapat dilihat pada Gambar 5 data yang telah diambil akan di ektraksi dan diolah di jetson nano dan akan di tampilkan pada web pain monitoring system. Untuk tahapan analisa face recognition ditunjukan oleh Gambar 6.

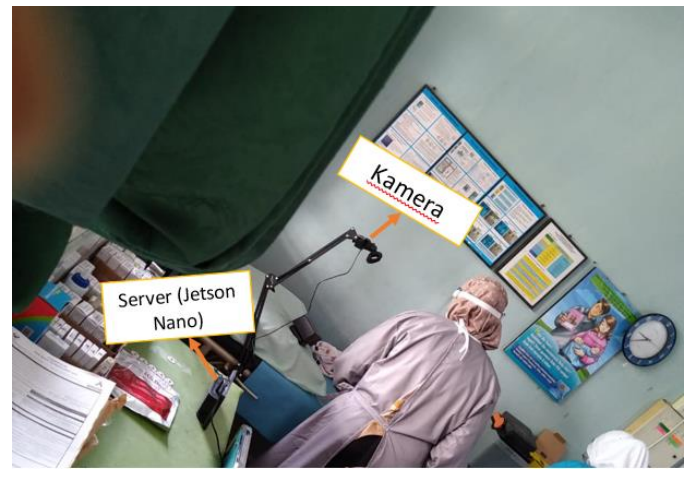

Gambar 5. Keadaan Saat Pengambilan Data Di Puskesmas Imogiri 1

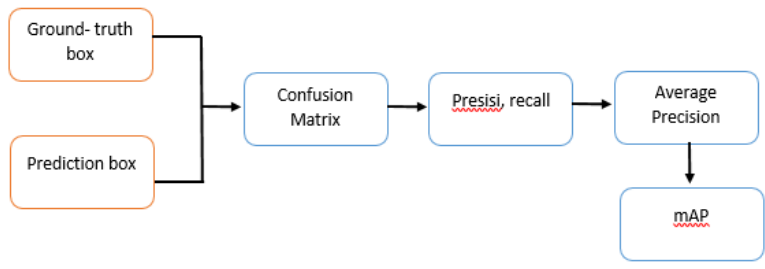

Gambar 6. Tahapan Evaluasi

Pada evaluasi pertama yaitu melihat data hasil testing anotasi dan hasil yang diperoleh data tersebut dapat dilihat pada Gambar 7.

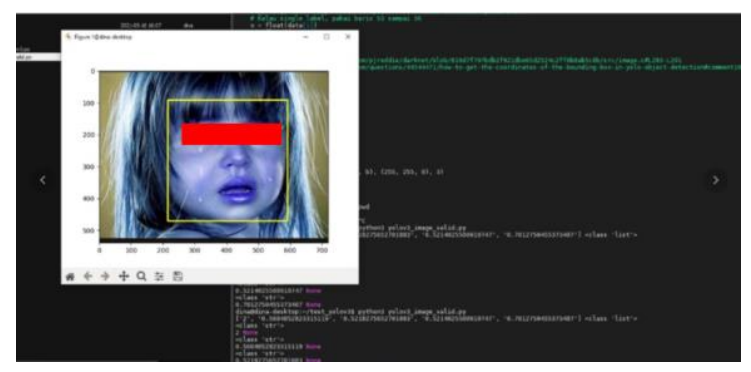

Gambar 7. Hasil Anotasi merah adalah hasil ground truth dan kotak hijau seperti terlihat pada Gambar 8.

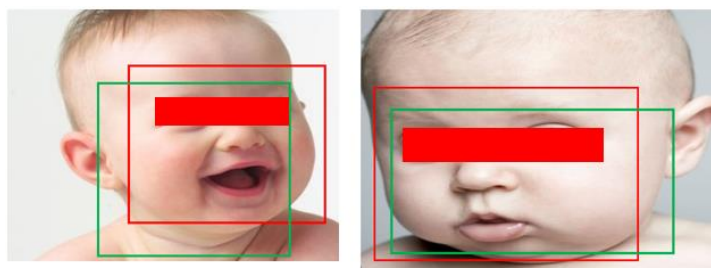

Gambar 8. Hasil Ground Truth Box Dan Prediction Box

Tahap selanjutnya adalah training model Pada sistem deteksi emosi wajah ini menggunakan batch 1 dengan epoch 50 yang artinya 1 data gambar akan dilakukan pelatihan data sebanyak $50 \mathrm{kali}$, hasil ini dipilih karena pada sistem menunjukan nilai mAP @0.5:0.95 ini berarti secara real case dengan iterasi dari akurasi 0,5 sampai 0,95. Dari data nilai mAP tes tersebut dapat diambil kesimpulan bahwa sistem sudah dapat mengenali model dengan baik dilihat dari nilai mAP yang lebih dari $50 \%$.

Untuk evaluasi selanjutnya yaitu dengan menguji model dan mempersiapkan data uji sebanyak 75 gambar dari gambar tersebut nantinya akan dilihat tingkat akurasi dari model yang digunakan. Pada Gambar 9 menunjukan data evaluasi dan Gambar 10 menunjukan hasil pengujian model.
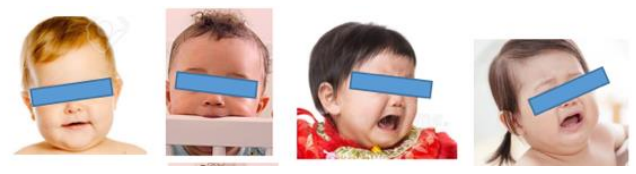

Gambar 9. Data Evaluasi Terhadap Model
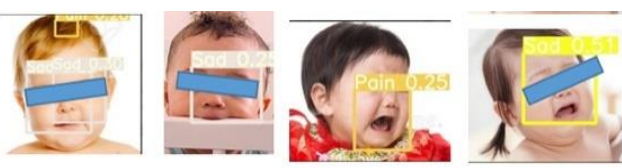

Gambar 10. Hasil Data Evaluasi Terhadap Model

Dari 75 gambar uji yang digunakan proses selanjutnya adalah menganalisa dengan menggunakan rumus 4 untuk mengetahui tingkat akurasi model, diperoleh sebanyak 45 gambar benar mendeteksi dari 75 gambar dan hasil akurasi didapat sebesar 70\%. Pada Tabel 1 ditunjukan hasil evaluasi model.

Tabel 1. Evaluasi Performa Model

\begin{tabular}{ccccc}
\hline Kelas & mAP@0.5 & $\begin{array}{r}\text { mAP@0. } \\
5: 0.95\end{array}$ & $\begin{array}{c}\text { Data } \\
\text { testing }\end{array}$ & $\begin{array}{c}\text { Akurasi } \\
(\%)\end{array}$ \\
\hline Netral & 0,992 & 0,76 & & \\
Nyeri & 0,969 & 0,68 & 75 & 70 \\
Sedih & 0,979 & 0,77 & & \\
\hline
\end{tabular}

Tahap evaluasi selanjutnya melihat ground truth box dan Lalu dilakukan sampling 10 data acak. Pengujian prediction box yang diperoleh dengan cara dilakukan secara langsung di puskesmas dan data membandingkan hasil yang telah di deteksi sistem sampling yang telah disiapkan, seperti yang di tampilkan dengan hasil label di labelme, di mana untuk kotak pada Tabel 2.

DOI: https://doi.org/10.29207/resti.v5i4.3184

Creative Commons Attribution 4.0 International License (CC BY 4.0) 
Tomy Abuzairi, Nurdina Widanti, Arie Kusumaningrum, Yeni Rustina Jurnal RESTI (Rekayasa Sistem dan Teknologi Informasi) Vol. 5 No. 4 (2021) 624 - 630

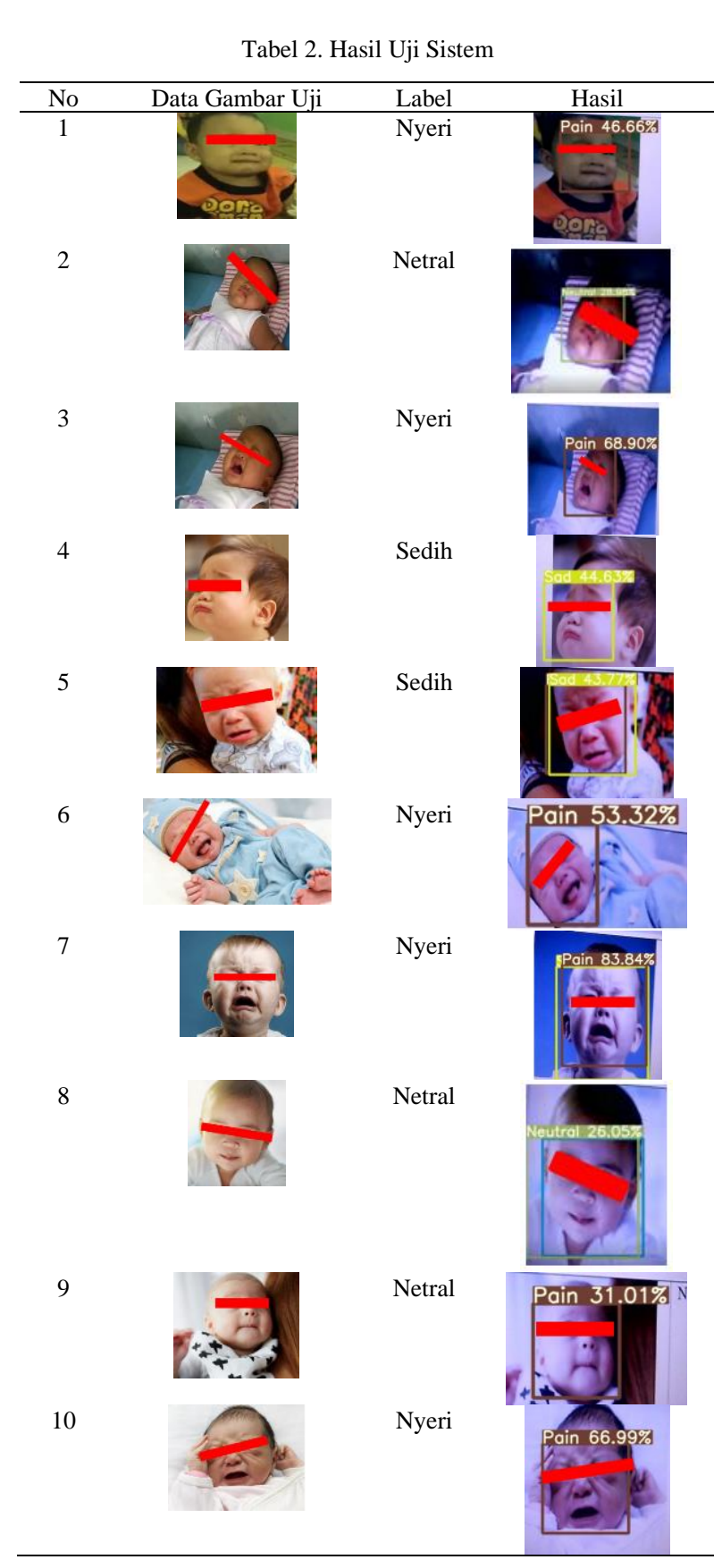

Dari data Tabel 2 tersebut akan dilakukan evaluasi dengan persamaan-persamaan $1-4$. Tabel 3 adalah hasil evaluasi dari data acak yang dilakukan. Tabel 4 adalah hasil dari nilai Confidence.

Tabel 3. Hasil Uji Evaluasi Data Acak

\begin{tabular}{|c|c|c|c|c|}
\hline Data acak & $\begin{array}{c}\text { Presisi } \\
(\%)\end{array}$ & $\begin{array}{c}\text { Recall } \\
(\%)\end{array}$ & $\begin{array}{c}\text { F1-score } \\
(\%)\end{array}$ & $\begin{array}{c}\text { Akurasi } \\
(\%)\end{array}$ \\
\hline 10 & 83 & 55,6 & 66,7 & 90 \\
\hline \multicolumn{5}{|c|}{ Tabel 4. Hasil Confidence } \\
\hline \multicolumn{2}{|c|}{ Data Gambar } & & \multicolumn{2}{|c|}{ Nilai Confidence (\%) } \\
\hline \multicolumn{2}{|c|}{1} & & \multicolumn{2}{|c|}{46,66} \\
\hline \multicolumn{2}{|c|}{2} & & \multicolumn{2}{|c|}{28,05} \\
\hline \multicolumn{2}{|c|}{3} & & \multicolumn{2}{|c|}{68,90} \\
\hline
\end{tabular}

\begin{tabular}{cc}
\hline 4 & 44,63 \\
5 & 43,77 \\
6 & 53,32 \\
7 & 83,84 \\
8 & 26,05 \\
9 & 31,01 \\
10 & 66,99 \\
Rata-Rata & 49,30 \\
\hline
\end{tabular}

\section{Kesimpulan}

Setelah melakukan seluruh tahapan dari mulai perancangan, pengujian dan juga analisa dan dapat diambil kesimpulan alat untuk mengukur tingkat rasa nyeri pada bayi sudah berhasil di buat dengan user interface berupa web. Untuk face recognition dibangun dengan framework phytorch dan algoritma YOLOV3, untuk dataset terdiri dari total 600 emosi bayi sedih, netral dan nyeri dengan rentang umur $0-12$ bulan dengan hasil mAP@0.5 sedih 97,9\%, netral 99,2\%, pada nyeri $96,9 \%$ dan akurasi model $70 \%$. Dengan kata lain algoritma YOLO ini sudah dapat mendeteksi sangat baik terhadap model yang diberikan. Dan saat dibuktikan dengan menggunakan data acak yang berasal dari pengambilan langsung di Puskesmas Imogiri 1 dan juga data referensi lain terbukti nilai akurasi menjadi $90 \%$. Berdasarkan hasil diatas dan telah diuji cobakan terhadap bayi secara real time dengan testimoni user langsung, bahwa pendeteksian rasa nyeri saat melakukan prosedur medis berupa imunisasi ini dapat membantu para bidan dan perawat disana.

\section{Kode Etik}

Penelitian ini sudah lolos kode etik sebelum dilakukannya tes kepada pasien, dengan nomor SK273/UN2.F12D1.2.1/ETIK.FIK.2019.

\section{Ucapan Terimakasih}

Penelitian ini dibiayai oleh Hibah Penelitian Dasar Unggulan Perguruan Tinggi (PDUPT) 2021 Nomor: NKB-214/UN2.RST/HKP.05.00/2021 dari Kementerian Pendidikan, Kebudayaan, Riset, dan Teknologi Republik Indonesia.

\section{Daftar Rujukan}

[1] Miftakhurrokhmat, R. A. Rajagede, and R. Rahmadi, "Presensi Kelas Berbasis Pola Wajah, Senyum dan Wi-Fi Terdekat dengan Deep Learning," J. RESTI (Rekayasa Sist. dan Teknol. Informasi), vol. 5, no. 1, pp. 31-38, 2021. https://doi.org/10.29207/resti.v5i1.2575

[2] R. mulyadi Yusni and Zaini, "Identifikasi Pengenalan Wajah Perokok Menggunakan Metode Principal Component Analysis," J. RESTI (Rekayasa Sist. dan Teknol. Informasi), vol. 4, no. 5, pp. 892-898, 2020. https://doi.org/10.29207/resti.v4i5.2272

[3] L. Farokhah, "Implementasi Convolutional Neural Network untuk Klasifikasi Variasi Intensitas Emosi pada Dynamic Image Sequence," J. RESTI (Rekayasa Sist. dan Teknol. Informasi), vol. 4, no. 6, pp. 1070-1076, 2020.

https://doi.org/10.29207/resti.v4i6.2644. 
[4] S. S. Panna and Betrisandi, "Klasifikasi Kelompok Usia Melalui Citra Wajah Berbasis Image Texture Analysis pada Sistem Automatic Video Filtering," J. RESTI (Rekayasa Sist. dan Teknol. Informasi), vol. 3, no. 3, pp. 429-434, 2019. https://doi.org/10.29207/resti.v3i3.1280.

[5] Y. Kristian, "Analisa citra wajah bayi untuk deteksi nyeri dan tangis menggunakan multi stage classification dan deep learning," 2018.

[6] H. Kahsay, "Assessment and treatment of pain in pediatric patients," Curr. Pediatr. Res., vol. 21, no. 1, pp. 148-157, 2017.

[7] Starship, "paediatric pain assessment", https://www.starship.org.nz/guidelines/paediatric-painassessment/.

[8] M. J. Hockenberry, C. C. Rodgers, D. Wilson, "Wong's essentials of pediatric nursing", Elsevier Health Sciences, 2021.

[9] R. W. Hall and K. J. S. Anand, "Physiology of Pain and Stress in the Newborn," Neoreviews, vol. 6, no. 2, pp. e61-e68, 2005 https://doi.org/10.1542/neo.6-2-e61.

[10]G. R. Lestari and T. Abuzairi, "Design of Portable Galvanic Skin Response Sensor for Pain Sensor," Proceeding - ICoSTA 2020 2020 Int. Conf. Smart Technol. Appl. Empower. Ind. IoT by Implement. Green Technol. Sustain. Dev., pp. 5-9, 2020. https://doi.org/10.1109/ICoSTA48221.2020.1570614094.

[11] J. J. J. Braithwaite et al., "A Guide for Analysing Electrodermal Activity (EDA) Skin Conductance Responses (SCRs) for Psychological Experiments," pp. 1-42, 2013, [Online]. http://www.bhamlive.bham.ac.uk/Documents/collegeles/psych/saal/guide-electrodermalactivity.pdf\%5Cnhttp://www.birmingham.ac.uk/documents/colle ge-les/psych/saal/guide-electrodermal-

activity.pdf\%0Ahttps://www.birmingham.ac.uk/Documents/colle ge-les/psych/sa.

[12]A. Tjahya, "Penilaian nyeri," Academia, pp. 133-163, 2017, [Online].

http://www.academia.edu/download/49499859/pemeriksan-danpenilaian-nyeri.pdf.
[13]C. Kit, "Using Pediatric Pain Scales," 2013, [Online] https://www.uwhealth.org/healthfacts/pain/7590.pdf.

[14]D. K. Wati, A. Pudjiadi, and A. Latief, "Validitas Skala Nyeri Non Verbal Pain Scale RevisedSebagai Penilai Nyeri di Ruang Perawatan Intensif Anak," Sari Pediatr., vol. 14, no. 1, p. 8, 2016. https://doi.org/10.14238/sp14.1.2012.8-13.

[15]D. M. Jensen, "towardd automated pain detection in children using facial and electrodermal," Physiol. Behav., vol. 176, no. 1, pp. 1570-1573, 2018. https://doi.org/10.1038/s41395-018-0061-4.

[16] M. W. Sullivan and M. Lewis, "Emotional expressions of young infants and children a practitioner's primer," Infants Young Child., vol. 16, no. 2, pp. 120-142, 2003. https://doi.org/10.1097/00001163-200304000-00005.

[17] R. A. Rajagede, "Modul CNN With Pytorch 0.4," 2018, [Online]. http://rianadam.web.ugm.ac.id.

[18]J. Redmon, S. Divvala, R. Girshick, and A. Farhadi, "You only look once: Unified, real-time object detection," Proc. IEEE Comput. Soc. Conf. Comput. Vis. Pattern Recognit., vol. 2016Decem, pp. 779-788, 2016. https://doi.org/10.1109/CVPR.2016.91

[19] github, "YoloV3," 2021. https://github.com/ultralytics/yolov3.

[20]R. Zhi, G. Zamzmi, D. Goldgof, T. Ashmeade, T. Li, and Y. Sun, "Infants' pain recognition based on facial expression: Dynamic hybrid descriptions," IEICE Trans. Inf. Syst., vol. E101D, no. 7, pp. 1860-1869, 2018. https://doi.org/10.1587/transinf.2017EDP7272.

[21]G. Zamzmi et al., "Convolutional Neural Networks for Neonatal Pain Assessment," IEEE Trans. Biometrics, Behav. Identity Sci., vol. 1, no. 3, pp. 192-200, 2019. https://doi.org/10.1109/tbiom.2019.2918619.

[22] THE CHILD AFFECTIVE FACIAL EXPRESSION SET (CAFE), "Dataset." [Online]. https://www.childstudycenter-rutgers.com/the-child-affectivefacial-expression-se. 